\title{
ACTIVE TECTONICS IN THE HELLENIC VOLCANIC ARC: THE KOLUMBO SUBMARINE VOLCANIC ZONE
}

\author{
Sakellariou D. ${ }^{1}$, Sigurdsson H. ${ }^{2}$, Alexandri M. ${ }^{1}$, Carey S. ${ }^{2}$, Rousakis G. ${ }^{1}$, \\ Nomikou P. ${ }^{1}$, Georgiou P. ${ }^{1}$ and Ballas D. ${ }^{1}$ \\ ${ }^{1}$ Institute of Oceanography, Hellenic Centre for Marine Research, POBox 712, 19013 Anavyssos, Greece, \\ sakell@ath.hcmr.gr,matina@ath.hcmr.gr,rousakis@ath.hcmr.gr,evi@ath.hcmr.gr, \\ pgeorg@ath.hcmr.gr,dballas@ath.hcmr.gr \\ ${ }^{2}$ Graduate School of Oceanography, University of Rhode Island, Narragansett, \\ haraldur@gso.uri.edu,scarey@gso.uri.edu
}

\begin{abstract}
This paper studies the rupture system of the Anydhros Basin, northeast of Thera island, and its relationship to the submarine volcanic activity along the Kolumbo line. Anydhros Basin is a $N 45^{\circ} \mathrm{E}$ trending elongate basin bounded by the Ios-Fault-Zone (IFZ) towards NW and by the AnydhrosFault-Zone (AFZ) towards SE. The AFZ continues southwestwards, crosscutting Thera Island. Swath bathymetry and seismic profiling data indicate that the Anydhros basin sedimentary infill is fractured by vertical, predominantly strike-slip faults, parallel to which the volcanic cones are aligned. We propose that the "KameniKolumbo Line" is an active, 40km-long, strike-slip fault zone. The KameniKolumbo strike slip runs through the volcanoes of Nea Kameni and Kolumbo and controls the spatial distribution of the volcanic cones along the axis of Anyhdros basin.
\end{abstract}

Key words: Anyhdros basin, swath bathymetry, seismic profiling, Kameni-Kolumbo strike-slip fault zone.

\section{Introduction}

The Hellenic Volcanic Arc has developed in the back arc region of the Hellenic subduction zone, parallel to and about 150km north of the Hellenic Arc (McKenzie, 1970; Le Pichon \& Angelier, 1979). The trace of the volcanic arc is delineated by the four main volcanic fields in South Aegean Sea, namely Methana-Egina, Milos, Santorini and Nisyros. The purpose of this paper is to correlate the spatial distribution of the active volcanic occurrences of the Santorini - Kolumbo volcanic field with the tectonic structure of the area and explore possible genetic relationships.

More than 20 volcanic cones aligned on a $\mathrm{N} 30^{\circ} \mathrm{E}$ trending zone have been mapped on the seafloor of Anydhros Basin, northeast of Santorini (Alexandri et al., 2003). By far, the largest of these submarine cones is Kolumbo, a $3 \mathrm{~km}$-diameter cone with a $1500 \mathrm{~m}$-wide crater, and a $505 \mathrm{~m}$ deep crater floor. Kolumbo was last active in $1650 \mathrm{AD}$, when an explosive eruption produced hot surges across the sea surface that caused 70 deaths on Thera (Fouqué, 1879; Dominey-Howes et al., 2000). A widespread hydrothermal vent field was discovered on the floor of Kolumbo's crater (Sigurdson et al., 2006). High-temperature venting occurs in the northern part of the crater, with vigorous gas emission plumes, and fluid temperatures up to $220^{\circ} \mathrm{C}$ from vent chimneys up to $4 \mathrm{~m}$ high. 
The Kolumbo submarine volcano was believed to have formed during a single eruptive phase in 1650AD (Fytikas et al., 1990; Perissoratis, 1995). Huebscher et al. (2006) have been able to observe in seismic reflection profiles two cone-like volcaniclastic deposits, which indicate that the Kolumbo volcano evolved from at least two eruptions. Bohnhoff et al. (2006) report that, the highest seismic activity in the area has been observed along the SW-NE striking Santorini-Amorgos zone. Within this zone the submarine Kolumbo volcano exhibits strong seismic activity which is interpreted to be directly linked to the magma reservoir and therein the migration of magma and fluids towards the surface. NE of Kolumbo they observed a similar seismicity pattern with smallscaled activity spots that might represent local pathways of upward migrating fluids or even developing volcanic activity within this zone of crustal weakness. Bohnhoff et al. (2006) conclude that the Santorini-Amorgos zone is presently in the state of right-lateral transtension. Dimitriadis et al. (2009) suggest that the seismicity observed underneath Kolumbo is associated with the "Kameni - Kolumbo Fracture Zone", which corresponds to the western termination of the major ENEWSW Santorini - Amorgos Fault Zone. Further on, they suggest that the NE Santorini - Kolumbo faults belong to a single rupture system. This interpretation is consistent with the hypothesis of Mascle \& Martin (1990), that the Aegean Sea may be considered as a stretching continental domain cut into ENE-WSW trending, elongate crustal terranes which move more or less independently towards the southwest.

Herewith we present results from the data collected mainly during a marine geological survey, conducted around Santorini from April to June 2006, in the frame of a collaborative project (NSF grant OCE-0452478) between the University of Rhode Island (URI-USA), the Hellenic Centre for Marine Research (HCMR-Greece), and the Institute of Geology and Mineral Exploration (IGME-Greece).

\section{Methods}

We use data obtained during several cruises in the area. First swath bathymetry of the study area was conducted in 2001 using the $20 \mathrm{kHz}$ SEABEAM 2120 swath system on R/V Aegaeo. The second survey took place in 2006 onboard R/V Aegaeo and R/V Endeavor and included complementary swath bathymetry data and refining of the existing map, airgun 10ci single channel seismic profiling (Fig. 1 ), gravity and box coring and ROV dives. Additional ROV dives have been performed in late 2006 during R/V Aegaeo cruise "Nautilus 2006".

\section{Results}

The Anydhros basin is a $\mathrm{N} 45^{\circ} \mathrm{E}$ trending, elongate basin developed between Ios and Koufonisia island to the NW and the Anydhros Islet and Anyhdros morphological ridge to the SE (Fig. 1). AnaphiAmorgos Basin is located southeast of the Anyhdros Ridge. The network of the seismic profiles presented here was designed to include lines both perpendicular and parallel to the axis of the basin, with the objective of revealing the structure of the basin, its margins and the relationship of the volcanic cones to the fault pattern.

The seismic profiles shown in Fig. 2a, 2b, 2c and $2 d$ run perpendicular to the axis of the basin. The Kolumbo fault in Fig. 2a is in alignment with several features of tectonic or inferred tectonic origin occurring on Thera and Therasia island like (i) the morphological discontinuity (inferred fault) of Kolumbo cape, (ii) the morphological depression (graben) of the caldera's rim between Imerovigli and Kokkino Vouno, (iii) the dense network of SW-NE trending volcanic dikes within this depression, (iv) the northen basin of Santorini's caldera and (v) the SW-NE trending volcanic dikes at the southern tip of Therasia island. 


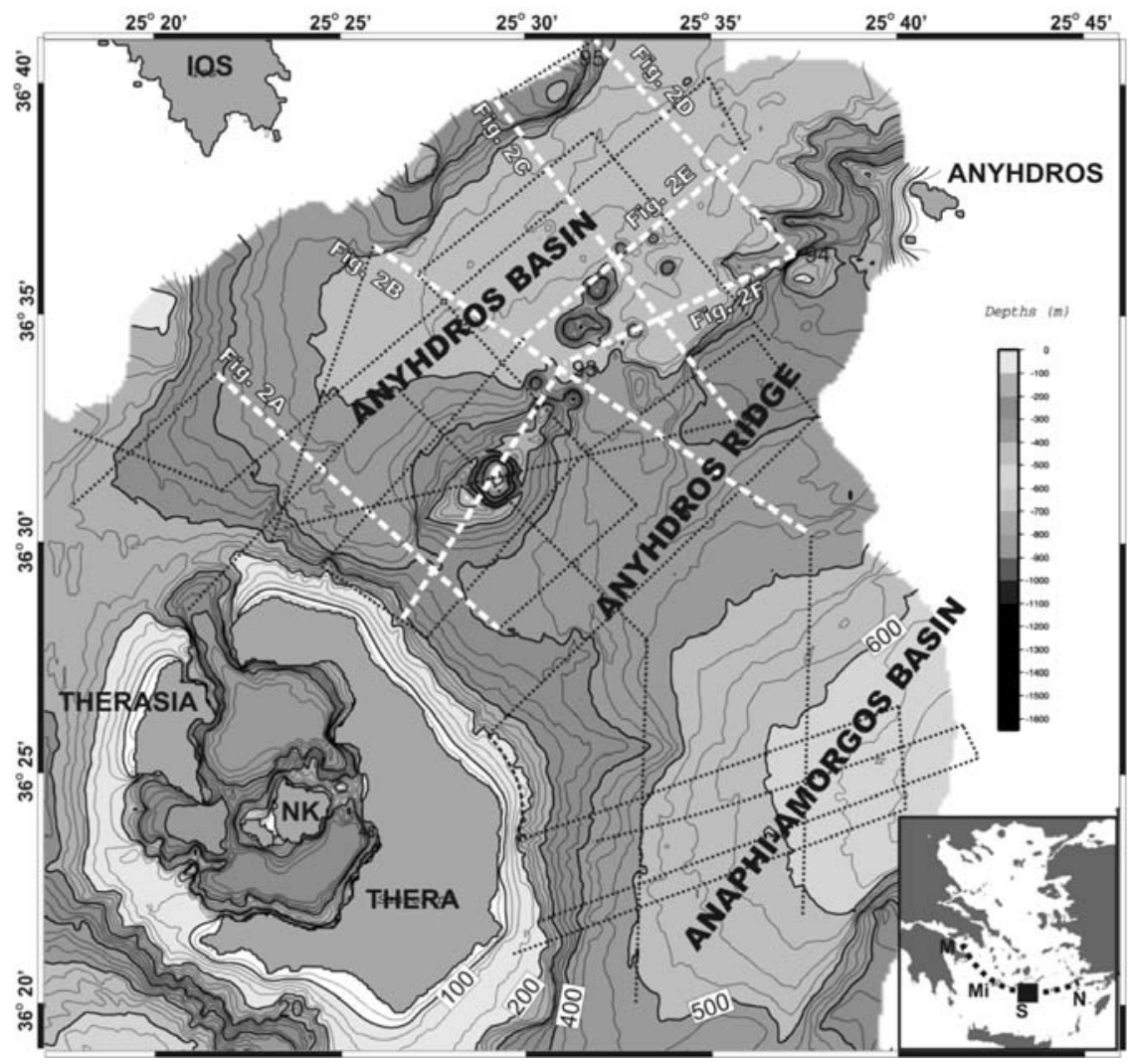

Fig. 1: Swath bathymetry map of the area east and northeast of Santorini Island (extracted from Alexandi et al. (2003) and Sigurdson et al. (2006). Thin black dotted lines show the tracks of the single channel seismic profiles. NK: Nea Kameni. Inset map: the dashed line delineates the Hellenic Volcanic Arc. M: Methana, Mi: Milos, S: Santorini, N: Nisyros.

The profiles of Fig. 2b, 2c and 2d illustrate the characteristic structure of the Anyhdros basin. Both margins of the basin are of tectonic origin and are developed along active faults. The basin is bounded towards $\mathrm{NW}$ by a segmented, $50 \mathrm{~km}$ long, $\mathrm{N} 45^{\circ} \mathrm{E}$ trending, linear fault zone, which can be traced all along the base of the SE-facing slope south of Koufonisia, Ios and Sikinos islands. Hereafter we call this fault zone Ios-Fault-Zone (IFZ). The SE margin of the basin displays more complicated morphological and tectonic character. It is formed by successive, en-enchelon arranged, fault segments which run $\mathrm{N} 30^{\circ} \mathrm{E}$ at the southwestern part of the margin and bend towards east-northeast at the northeastern part of it. Hereafter we call this complex fault zone Anydhros-Fault-Zone (AFZ). The traces of the observed faults are shown on the map of Figure 3.

The $15^{\circ}$ difference in the orientation of the two basin bounding fault zones results in a significant narrowing of the Anydhros basin towards NE. Thus, the distance between the Ios-Fault Zone and the Anydhros-Fault-Zone is about $30 \mathrm{~km}$, measured SW of Thera Island, it becomes $16 \mathrm{~km}$ across the Kolumbo volcano and decreases to only $8 \mathrm{~km}$ northeast of Anydhros islet.

The thickness of the sedimentary pile deposited in the Anydhros basin may locally be as large as $500 \mathrm{~m}$. No major discordance of sedimentary origin has been observed within the basin infill. The 

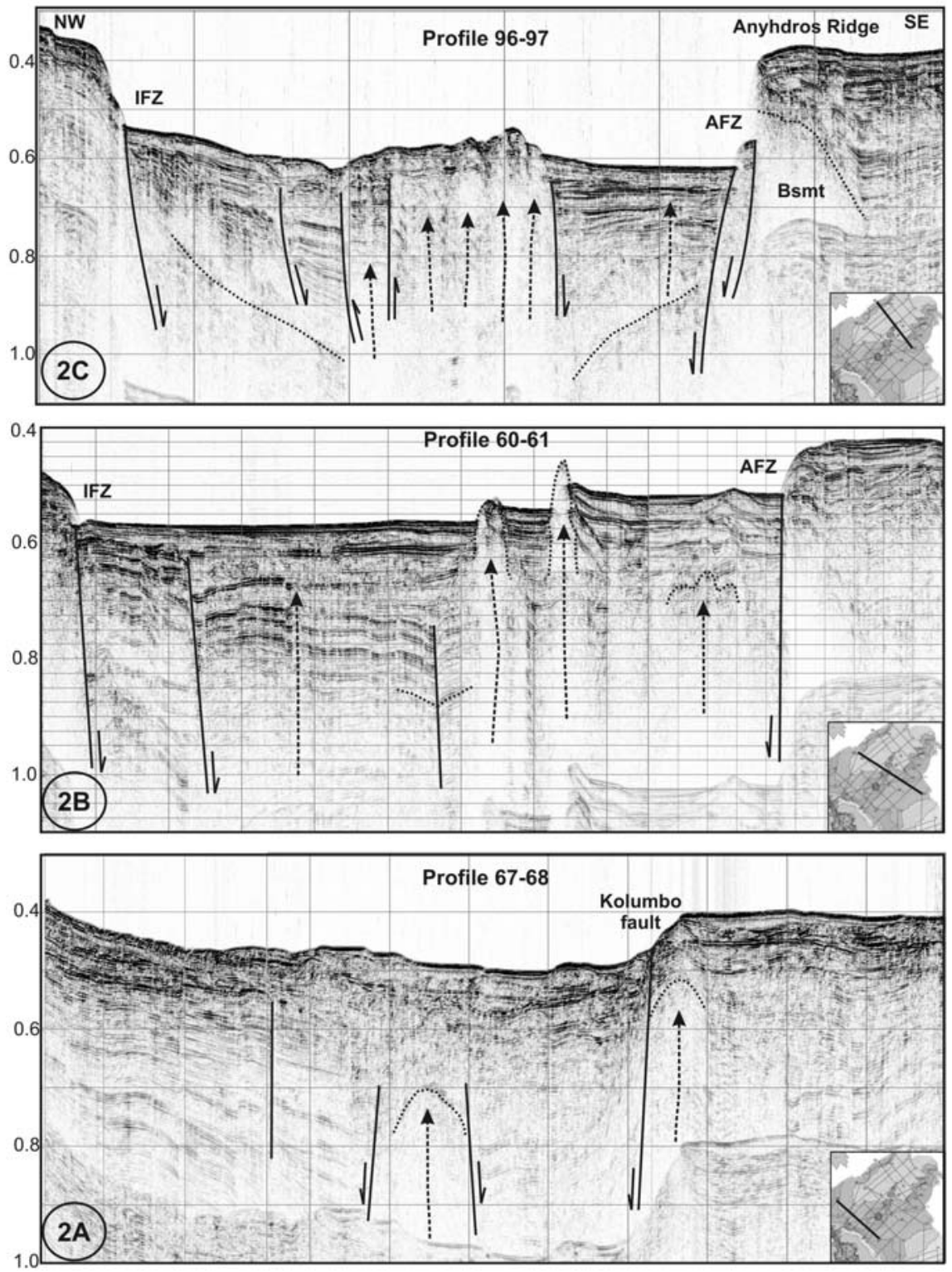

Fig. 2: a - c. Airgun 10ci single channel profiles from the Anyhdros basin. Dashed arrows show ascending magmatic fluids. Dotted lines highlight dominant features of the subseafloor where needed. AFZ: Anyhdros Fault Zone, IFZ: Ios fault Zone, Bsmt: Alpine Basement. See text for explanation and interpretation of the profiles.

sedimentary layers are intensively deformed and ruptured by vertical or subvertical faults, which run parallel to the Anydhros-Fault-Zone. Some of them display normal character, indicating extensional regime, but in most cases, the sense of movement of these faults is not obvious. For example hangingwall and footwall of a certain fault can be distinguished in one seismic line, but this may not be the case for the same fault on the next line. This is a strong evidence to attribute predominantly strike-slip character to these faults and assume a transtensive deformational regime within the Any- 

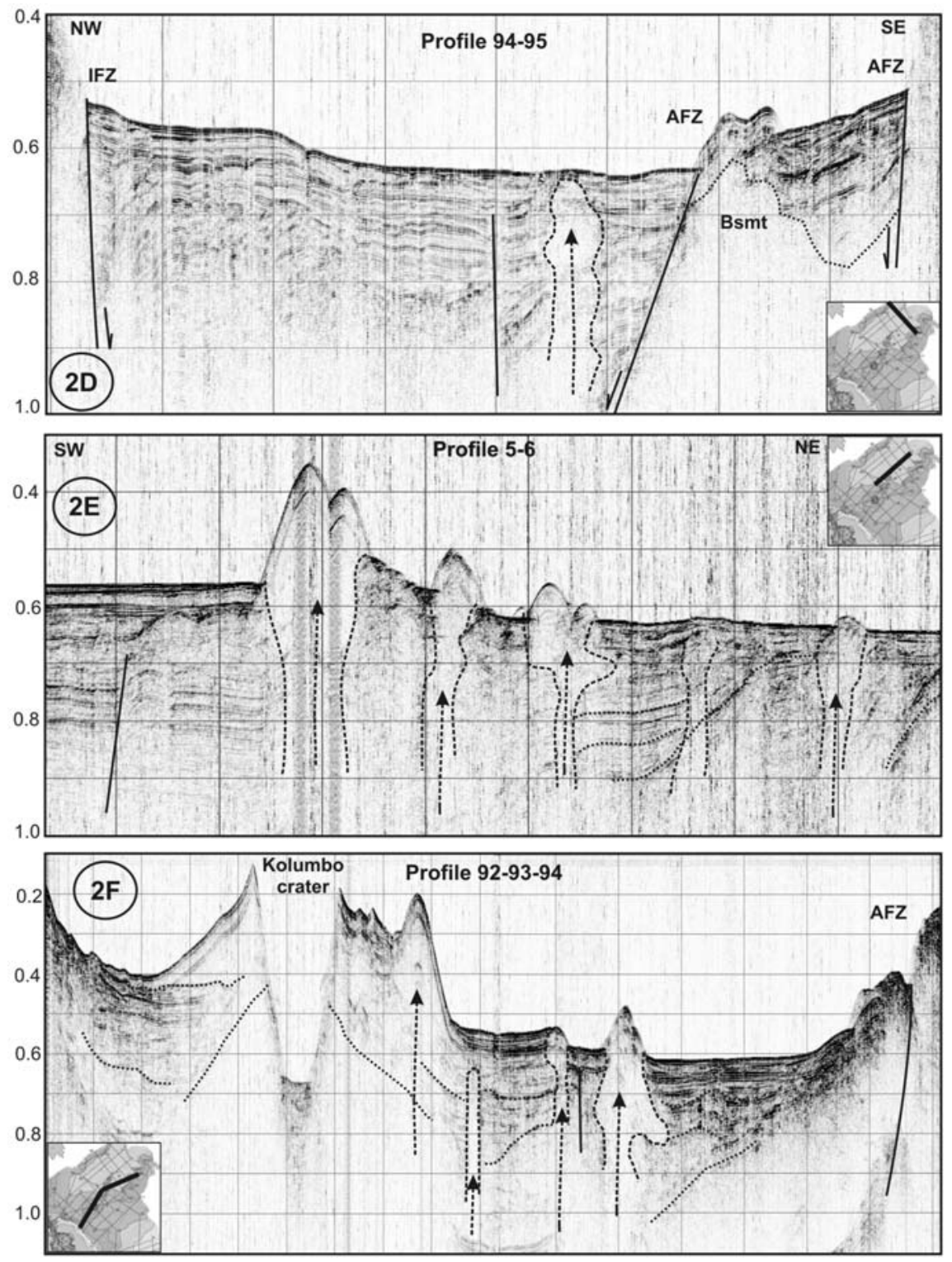

Fig. 2: $d$-f. Airgun 10ci single channel profiles from the Anyhdros basin. Dashed arrows show ascending magmatic fluids. Dotted lines highlight dominant features of the subseafloor where needed. AFZ: Anyhdros Fault Zone, IFZ: Ios fault Zone, Bsmt: Alpine Basement. See text for explanation and interpretation of the profiles.

hdros basin. This interpretation is in agreement with the right-lateral transtensional character observed from seismological data by Bohnhoff et al. (2006) and Dimitriadis et al. (2009).

Areas of diffuse or transparent acoustic character crosscutting the sedimentary layering of the basin are delineated by dashed lines and indicated by dashed arrows pointing upwards in all six profiles of Figure 2. They are always located below the volcanic domes, while some of them die out before reaching 
the seafloor. The sedimentary layers are being dragged upwards at their contact to these diaper-like structures. We interpret them as conduits of the ascending magmatic fluids. They are associated with the existing ruptures, indicating that the latter are preferred weak zone for the magmatic fluid flow.

The profile of Figure 2e runs parallel to the long axis, in the middle of Anyhdros basin. It crosscuts the series of volcanic domes aligned on the axis of the basin. It is evident that the size and the height of the volcanic domes decreases towards the northeast, indicating that the volcanic activity diminishes as the distance from Kolumbo increases. Deformation of the sedimentary layers is obvious in this profile too, indicating that the deformation regime is much more complicate than that expected in normal, extensional basins.

The structure of Kolumbo submarine volcano is shown on the profile of Figure $2 \mathrm{f}$. The interpretation of this profile suggests that at least one older volcanic cone exists and is located underneath the present one, indicating that Kolumbo has been active at least once, prior to the 1650 eruption (see also Huebscher at al., 2006). Layered or massive lava flows form the lower part of the present Kolumbo cone and are displayed as stratified, high amplitude, subhorizontal reflectors on the profile. The upper part of the cone shows transparent acoustic character and is composed of tephra deposits produced during the 1650 eruptive phase. This interpretation has been verified by repetitive ROV dives in the Kolumbo crater and at different sites of the inner crater walls.

Further observations during the ROV dives on the 500m deep crater revealed that the observed chimneys, described by Sigurdson et al. (2006), along with ridge-like structures (possible dikes) are mostly aligned in NE-SW direction, parallel to the Kolumbo-Line. This preferred orientation of the volcanic and hydrothermal features may be controlled by the dominant tectonic trend.

\section{Conclusions}

Integrated evaluation of the swath bathymetry of the Anydhros basin (Alexandri et al., 2003; Sigurdson et al., 2006) and the seismic profiling data presented here indicates that the linear distribution of the volcanic cones is controlled by strike-slip faults which run parallel to the long axis of the basin. These faults have been and are being presently used as conduits for the upward migration of the magmatic fluids. This $\mathrm{N} 30^{\circ} \mathrm{E}$ trending tectonic-volcanic zone is in line with (i) the northern basin of Santorini caldera, (ii) the morphological (and tectonic?) graben developed on NE Thera island, between Kokkino Vouno and Imerovigli and (iii) the Kolumbo cape in NE Thera Island. It is also in line with the occurrence of dense networks of SW-NE trending volcanic dikes both in the Kokkino Vouno Imerovigli graben and the southernmost tip of Therasia Island. It is also worthnoting that observations made by ROV dives in the Kolumbo crater indicate that the actively venting hydrothermal chimneys are aligned in SW-NE direction, while similarly directed fractures have been observed both on the crater's seafloor and the steep inner walls.

We conclude that the previously defined "Kolumbo Line" is an active, possibly right-lateral, 40kmlong, strike-slip fault-zone. It constitutes a zone of weakness, which has enabled the upward migration of magmatic fluids, the creation of dikes and the development of submarine volcanic cones, with Kolumbo submarine volcano as the most productive among them. Furthermore, we suggest that the "Kameni-Line" is directly related to and displays similar characteristics with the Kolumbo Line. Kameni and Kolumbo Lines represent two en enchelon arranged segments of one single strike slip fault zone developed parallel to the Anydhros Fault Zone. The location of the active Nea Kameni volcano coincides with the relay zone between the two fault segments.

We propose that the Anydhros-Fault-Zone continues southwestwards, crosscutting Thera Island and 


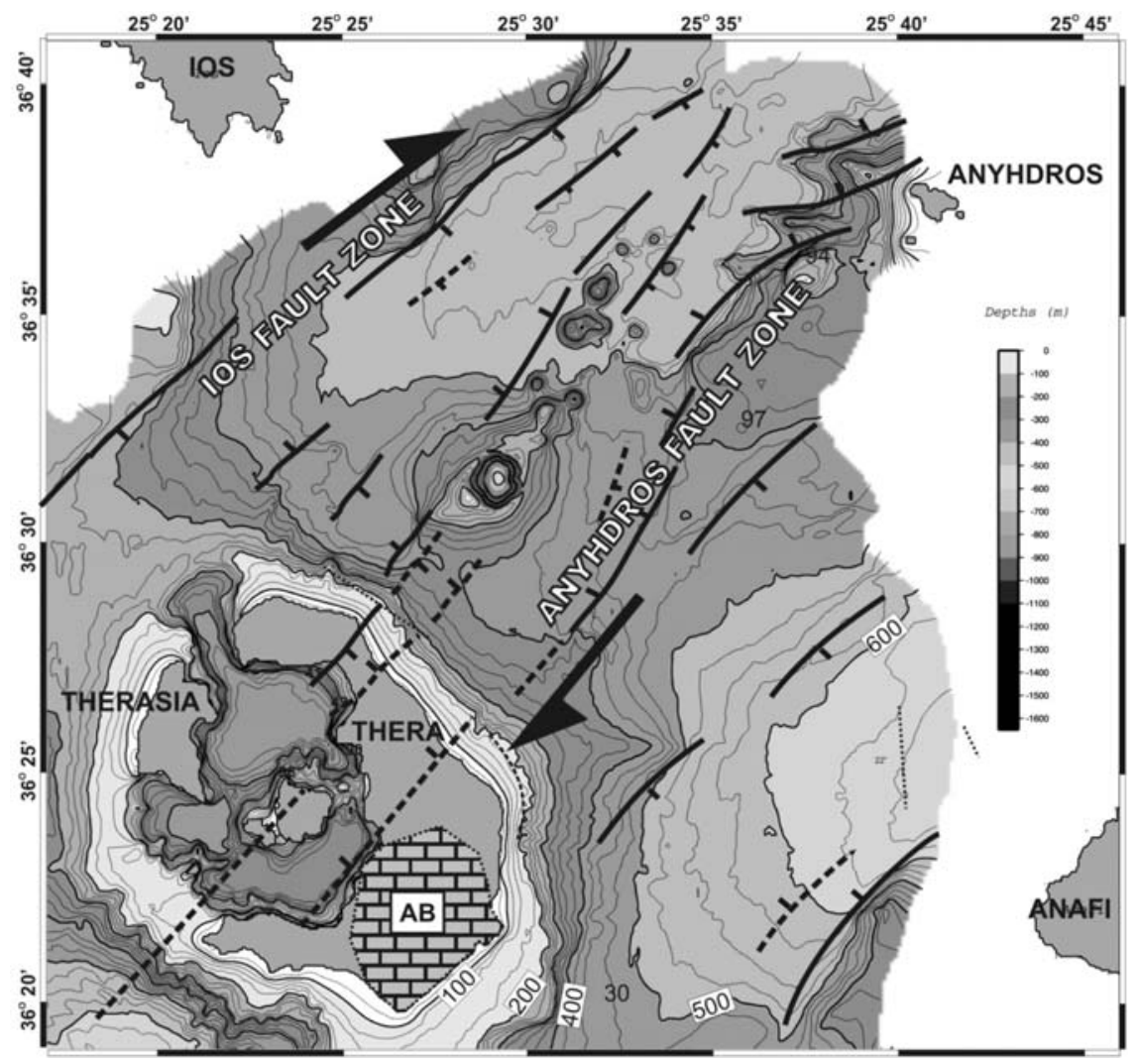

Fig. 3: Tectonic map of Santorini - Kolumbo volcanic field. Swath bathymetry as in Fig. 1. AB:Alpine Basement.

can be traced as far south as Christiana Islet. The prolongation of the AFZ towards the southwest coincides with (i) the southern steep margin of the Santorini Caldera's southern basin, (ii) the northern limit of the alpine basement on Thera Island and (iii) the northern flank of the submarine ridge southwest of Thera. The geological data presented here indicate that the southern part of Thera Island and the Anydhros Ridge form a structural high of the alpine basement.

In addition, we propose that the volcanic activity of the Santorini-Kolumbo field preferentially develops within the transtensional regime which created Anyhdros Basin. The two marginal fault zones of the basin, the Ios and the Anydhros fault zones, may be considered as the two main splays of a single strike slip fault zone which runs underneath the basin and along its axis. Together with the intrabasinal subvertical faults they form a kind of flower structure, typically observed along strike slip fault zones. We call this fault zone hereafter the Kameni-Kolumbo strike slip. This hypothesis explains the transtensional character of the Anyhdros basin and the deformation pattern of the sedimentary infill. It is also consistent with the upward migration of the magmatic fluids and the preferred alignment of the volcanic centres along the basin axis.

\section{References}

Alexandri, M., Papanikolaou, D., Nomikou, P., and Ballas, D., 2003. Santorini volcanic field - New insights based on swath bathymetry. Abstracts IUGG 2003, Saporo, Japan. 
Bohnhoff, M., M. Rische, T. Meier, D. Becker, G. Stavrakakis, and H.-P. Harjes 2006. Microseismic activity in the Hellenic Volcanic Arc, Greece, with emphasis on the seismotectonic setting in the Santorini-Amorgos zone. Tectonophysics, 423 (2006) 17-33.

Dimitriadis, I., Karagianni, E., Panagiotopoulos, D., Papazachos, C., Hatzidimitriou, P., Bohnhoff, M., Rische, and M., Meier, T., 2009. Seismicity and active tectonics at Coloumbo Reef (Aegean Sea, Greece): Monitoring an active volcano at Santorini Volcanic Center using a temporary seismic network. Tectonophysics, in press (doi: 10.1016/j.tecto.2008.11.005)

Dominey-Howes, D.T.M., G.A. Papadopoulos and A.G. Dawson, 2000. Geological and historical investigation of the $1650 \mathrm{Mt}$. Columbo (Thera Island) eruption and tsunami, Aegean Sea, Greece. Natural Hazards, 21, 83-96.

Fouqué, F. 1879. Santorin et ses Éruptions, Masson et Cie, Paris.

Fytikas, M., N. Kolios, and G. Vougioukalakis (1990), Post-Minoan volcanic activity of the Santorini volcano: Volcanic hazard and risk, forecasting possibilities, in Thera and the Aegean World III, vol. 2, Earth Sciences, edited by D. A. Hardy, 183-198, Thera Found., Essex, UK.

Huebscher, C., Hensch, M., Dahm, T., Dehghani, A., Dimitriadis, I., Hort, M., Taymaz, T., 2006. Toward a Risk Assessment of Central Aegean Volcanoes. EOS, Vol. 87, No. 39, 26 September 2006.

Le Pichon, X., Angelier, J., 1979. The Hellenic arc and trench system: a key to the neotectonic evolution of the Eastern Mediterranean area. Tectonophysics 60, 1-42.

Mascle, J. and Martin L., 1990. Shallow structure and recent evolution of the Aegean Sea: A synthesis based on continuous reflection profiles. Marine Geology 94, 271-299.

Mc Kenzie, D.P., 1970. Plate tectonics of the Mediterranean region. Nature 226, 239-243.

Perissoratis, C. 1995. The Santorini volcanic complex and its relation to the stratigraphy and structure of the Aegean arc, Greece, Marine Geology, 128, 37-58.

Sigurdsson H., Carey S., Alexandri M., Vougioukalakis G., Croff, K., Roman C., Sakellariou D., Anagnostou C., Rousakis G., Ioakim C., Gogou A., Ballas D., Misaridis T., and Nomikou P., 2006. Marine Investigations of Greece's Santorini Volcanic Field, EOS, Vol 87 N. 34, 22 August 2006. 